\title{
Types of communicative activities and communication for the information exchange as lingvo-cognitive aspects of the SPEECH concept
}

\author{
V. M. Smaglii \\ Odessa National Maritime University, Odesa, Ukraine \\ Corresponding author. E-mail: valeriya.smagliy@ gmail.com
}

Paper received 23.10.18; Accepted for publication 28.10.18.

\begin{abstract}
https://doi.org/10.31174/SEND-Ph2018-182VI53-11
\end{abstract}
\begin{abstract}
Having analyzed the nuclear zone of the investigated concept, the sector "communication" of the medial zone of the field is investigated as it is the most numerous in terms of the number of included lexemes. The lexemes are considered and systematized by groups and comparative thematic groups "types of communicative activities" and "communication for information exchange" as linguistic and cognitive aspects of the SPEECH concept for the further development of this classification. The social approving and disapproving qualities of human communication are defined.
\end{abstract}

Keywords: Concept, speech, medial zone, communication, thematic group, lexeme.

Introduction. Starting a linguo-cognitive study of this concept in the English-language picture of the world, we proceed from the premise of O.Kubryakova that the meaning of the sign is "a concept captured by a sign" [2, p.31]. Such analysis involves, firstly, the selection of lexical units that nominate the investigated concept. Secondly, the dictionary definitions, which are offered by general lexicographic sources, are subject to analysis. Thirdly, there is a definitive analysis of the data obtained, which allows one to distinguish from them a set of discrete semantic units - semes which being semantical (that is, non-material) entities, acquire their "material" embodiment in the form of definitions, recorded in the explanatory part of the vocabulary articles.

Analysis of recent investigations and publications. The expediency of the definition analysis as the starting stage of studying the nominative field of the concept follows from the fact that, as V. Evans indicates, "the definition creates the so-called lexical profile of the concept "[8, p.22]. According to G. Ufimceva, "significant significance can be expressed in metamiliar way, widely used in lexicographic practice" [7, p.31]. It is worth noting that "value does not represent an indivisible whole, but consists of a set of components that have autonomy" [6, p.81].

V. V. Kodyukhov writes about it: "Every meaning of the word is a collection of semantic features (semes) that form the structure of meaning" [1, p.101]. M. Nikitin specifies: "Seme is a non-uniform part of the value" [5, p.117]. Its explication takes place through the mediation of definitions that are removed from the vocabulary of the corresponding lexical unit.

Setting goals. After analyzing the nuclear zone of the investigated concept, we proceed to a much more comprehensible and more diversified zone of its verbalized field. The communication field of the medial zone of the field is the most numerous in the number of lexemes included, which counts about two and a half hundred units. In turn, this sub-sample is subject to further thematic grouping.

Results and their discussions. The thematic group of types of communicative activities covers the nominations of human actions such as reading, writing, recitation, etc. The SPEECH group has already been analyzed earlier in the nuclear zone in the speech / to speak segment.
Among the listed types of communicative activity, the most lexicographically documented, and thus refined social consciousness, is writing. Hyperonism in this subgroup is the writing lexeme, which has three different denotational structures: a) writing as graphic activity [the act of forming visible letters and symbols on a surface], [the process of producing and recording words that can be read and understood] , b) writing as a creative process and product of this process [the activity of composing texts for publication], [smth written, esp. literary composition] and c) graphic art product [inscription], [smth written, such as a letter, a note].

Hyponymic lexemes of this subgroup specify the process of graphic fixation and the appearance of the graphic icons. In particular, the handwriting and typing nouns specify how writing is being done hand-written using pencil, pen or typewriter, in the definitions there is an additional sign: handwriting [writing with a hand, with a pen or pencil]; typing [writing by means of a typewriter or computer].The appearance of graphic icons is explained in the cursive lexeme [manuscript written in cursive characters] <- [having the successive letters joined together]; in addition, the second level of defining analysis leads to the defining characteristic [manuscript], which is etymologically derived from lat. manuscriptum $=$ manus (hand) + scribere (to write), and therefore refers to the handwritten semantics. The appearance of such a written text obviously resembles a manuscript. The most interesting is the text lexeme, which in its composition contains such a marginal sememe that explains the appearance of the graphics [fine, large handwriting, used esp. for manuscripts].

The technology of the writing process is reflected in the opposed pair of nominative units: shorthand VS longhand. The first of these is a shorthand, writing script [writing rapidly by substituting characters, abbreviations or symbols for letters, sounds, words or phrases, stenography]. Definitive signs will expose the speed of such a letter and its techniques - the replacement of certain parts of the message with conditional icons. Seven abbreviations have not been identified in the definition, it manifests itself through the root morpheme short- in the compound word shorthand. The word longhand is a morphological antonym to shorthand, but its semantics is wider. In addition to contrasting the longhand cursive, [characters or words written fully] $=$ the spelling of words in a 
complete, non-abbreviated form, the word longhand also means handwritten writing, as opposed to typing or printing. Thus, the formal opposition in this pair of nouns looks more coherent than semantic.

The thematic group communicative activity includes the nomination of the processes of reading, while in the framework of the reading lexeme, there is a clear separation of the semes into the notation of receptive and productive communicative activity. The first of these is defined through the reference of the noun read to the verb to read [receive the sense of letters, symbols, esp. by sight; look and understand the meaning of written matter by interpreting the characters or symbols of which it is composed]. Analyzing the definitions of these interpretations we get a set of semes: 1) perceive vision, 2) graphic icons, 3 ) interpretation, 4) their meaning. This type of communicative activity is traditionally called "reading about oneself" in contrast to "reading aloud." Researchers argue that "reading aloud" is historically preceded by "reading about oneself" and this is due to the technique of writing, which for a long time was continuous (Latin scriptia continua), that is, without being divided into graphic words, without punctuation. Verbal spaces in writing appeared only in the VII century in the British Isles [4, p.35]. Y.P.Melenteva notes: "Reading aloud enabled the reader to understand the content of the text written by a continuous letter. Reading the texts meant their vocalization, and the readers were, in fact, listeners of the voice of the reader. What was written was perceived as a certain image, according to which, until it "read aloud", the contents is hidden"[4, p.57].

The sememe of the reading noun with the meaning of "reading aloud" is defined as [the act of rendering aloud written or printed matter]; it also refers to the corresponding verb seme to read [utter aloud the printed or written words]. The seme set of this lexical unit includes 1) pronouncing aloud, 2) what is written (a set of graphic characters). The third seme reading [material read or for reading], [written or printed matter that can be read], [piece of literature, passage of scripture that is read aloud] is derived from the first and second, calling the object or the receptive, or productive varieties of communicative activity of reading. The set of semes in this case covers 1) a written text that will be; 2) perceived by sight; or 3) pronounced aloud.

Thematic group types of communicative activity include the nominative unit utterance [the action of saying or expressing smth aloud; vocal expression]. This unit includes a set of semes 1) vocalization, 2) content. The qualitative characteristic of the vocalization process is expressed in the semes of whisper [a soft or confidential tone of voice; smth uttered very softly], here the leading is the seme of the small volume of speech: 1) quiet, 2) speaking aloud. Very rare technique of vocalization is the so-called the ventriloquism [the production of the voice in such a way that the sound seems to come from a source other than the vocal organs of the speaker, as from a wooden figure]. Such technique is used predominantly by the actors of the conversational genre in populated rooms with false dialogues, who run a speaker and a doll in his hands. Oral reproduction of the learned text is another kind of communicative activity of the individual; it is denoted by the noun recitation $=$ recitation $[$ repeating smth aloud from memory], which can be used as a clarifying defining characteristic of the educational nature of such activity [oral delivery of a prepared lesson by a pupil].

The educational character of another communicative activity - dictation - is followed as an additional defining feature in certain semantics of lexeme dictation [the activity of taking a passage that is dictated by a teacher as a test of spelling, writing, or language skills)], although the main meaning contains less set of semes: 1) spoken 2) words for their 3) record [dictating words to be typed, written down, or recorded; uttering words to be transcribed]. Let's pay attention to the verb to transcribe, noting that this is a written letter entry, not a phonetic transcription: to transcribe [to make a copy of dictated matter in a longhand or on a typewriter]. Dictionaries do not fix the nominative meaning of transcribing. The lexical unit spelling names the communicative competence of the spokesman in the field of spelling [art of orthography; the activity of writing or naming the letters of a word]. A widespread and well-known type of communicative activity is translation [a written or spoken rendering of the meaning of a word or text in another language], the product of such activity is indicated by another seme of the lexeme translation - the translation of [the product of such rendering; a translated version of a text.] The translation of the content of the message [rendering of the meaning] involves the use of a foreign language code, which results in the creation of two or more versions of the same message, which (ideally) are identical in content, but different in linguistic form of expression.

A communicative action, which is denoted by the nominative unit of a paraphrase, is somewhat similar [restatement of a text, passage, or work giving the meaning in another form; rewording of smth written or spoken. The expediency of providing a new verbal form to what has already been explained in some dictionaries by an additional defining feature: [restatement of a text in other words as a learning or teaching device.] That is the explanatory or educational guide for such an action. Such an effect as word formation is called coinage [the invention of new words] with a fairly transparent etymology: in the Middle English the word came in the form of borrowing from the Old French coigniage <--- coigner (to mint), in English of that period it meant chokan, coin stamp [a die for stamping money]. Metaphorization (the transfer of the idea of coinage of new coins to the formation of new words) led to the appearance of a verb noun coinage with a value that encompasses the following seven: 1) creation, 2) new, 3) words. In total, 17 nominating units are part of the analyzed thematic group.

The thematic group communication for the exchange of information is as numerous as the previous one. First of all, it includes the general values of lexemes, which name the process of communication as such. The communication lexeme opens this list. In its definitions, we distinguish the basic semes: 1) exchange, 2) thoughts / information by means of 3) signs (in particular, linguistic): [exchange of thoughts, information as by speech, signals, writing; by some other medium]. The value of this first seme is specified in the second seme communications through the use of qualitative seme effective [techniques for the efficient use of words to impart information and 
ideas]. The synonym to the noun communication is (but in somewhat narrowed sense) the first sememe of the registered lexeme discourse, referring solely to verbal communication [verbal interchange of ideas; written or spoken communication], the second semantics further specifies the semantics by adding semes: 1) officiality, 2) ordering, 3) length: [formal and ordered expression of a subject, either written or spoken]. Another synonym for the noun communication is a conversation that refers to an exchange of thoughts, but not an official one but a private [conversation between two or more people in which news and ideas are exchanged]. The conversation noun in turn has synonyms colloquy, confab [informal, private conversation]. The peripheral seme of the registered lexeme rhetoric is also included in the synonym chain with the base unit of communication and means of verbal communication in general [verbal communication, discourse]. In this case, the main seme of rhetoric is the more expressive and convincing verbal communication [the art, the skill of effective or persuasive speaking or writing], this skill further specifies the meaning of the sememe, emphasizing the complexity and desirability of such communication.

Another variant of specifying a value is another marginal sememe rhetoric [language that is elaborate, pretentious, insincere, or intellectually vacuous; language designed to have a persuasive or impressive effect, but which is lacking in sincerity or meaningful content]. Distinguished emphasis on definitions in dictionary interpretations clearly indicates the pejorative estimated colour of this sememe rhetoric. As we see, within the framework of a single rhetoric lexeme, two oppositely evaluable sememes coexist: one in the indication of expressive convincing communication (positive appreciation), the second in the designation of the insincere, meaningless communication (negative evaluation).

Communication for the exchange of ideas and the achievement of a certain solution is the meaning of lexeme discussion [consideration of a question; talking about smth in order to reach a decision or to exchange ideas]. Somewhat differently, the second sememe of this lexeme is defined: discussion [formal treatment of a topic], [a detailed treatment of a topic in speech or writing]. Here we distinguish semes: 1) thematic integrity and 2) the formal / detailed nature of the discussion of the issue. At the same time, the word discussion as a sign of a defining feature is registered in a number of other hyponymic vocabulary units. Deliberation [long and careful consideration or discussion; careful discussion done in order to make a decision] - the thoroughness of the discussion (for making a decision) is emphasized in this lexeme. On the basis of formality / informality, the lexemes opposed are disquisition [a formal inquiry into a subject of a subject] VS bull session [an informal discursive discussion].

Communication channel in communication acts as a semantic character of the chat seme [online discussion; synchronous exchange of remarks over a computer network]. Long time and the boring character of conversations is accentuated in the units of talkathon [lengthy session of discussions, speeches], palaver [prolonged and tedious discussion], the latter of which has separate sememes with even more limited meanings, for example, [a long parley usually between persons of different cultures ]
- long communication between representatives of different cultures; two more sememes of the palaver contain negatively evaluated semes purposeless, deceptive communication: [idle talk, chatter], [talk intended to beguile, misleading speech]. In the discussed thematic group, the talk lexeme occupies a certain place. The main sememe of talk has a generalizing meaning [exchange of ideas; communication by spoken words, conversation, discussion], its complete synonym is an outdated sememe of lexeme tale (obsolete) [discourse, talk]. The nature of communication is indicated in the definition of another sememe. Talk [conversation or discussion, esp. a serious one], has a negative assessment of the nominated form of communication in the sense of another sememe talk [pointless or fruitless discussion, verbiage; empty speech or unnecessary discussion; empty promises or boasting] a number of definitions (underscored) verbalize the seme aimless, verbose, empty, boastful, superfluous, taken together, very negatively qualify such communication. A whole cluster of registered noun lexemes consult, consultation, consultancy denote the communicative effect of counseling, that is, communication that involves an expert in a particular area (medical, legal, etc.). [A meeting in which someone (such as a doctor or lawyer) talks to a person about a problem, question; a meeting with an expert, such as a medical doctor, in order to seek advice].

Communication aimed at working out a certain agreement between the parties is nominated by a lexeme negotiation [discussion aimed at reaching an agreement]. Official negotiations are also nominated as a separate sememe talk (s) [a formal discussion, negotiation]. Such a communicative event is based on the procedure and may precede the previous communicative event [a discussion preliminary to negotiations]. The form of this noun clearly shows the borrowed character of the word: it became part of the English language from the Middle French, in ancient French was formed from the preposition por [before] and the verb parler [to speak]. Communication is specific for the exchange of information in military, and further spyware purposes: to protect a particular territory or object from unauthorized entry there, third parties have long been using a password system, pre-agreed words or phrases known only to secret individuals. Calling a password served as a signal to pass the person to a classified object or territory. There are a number of Englishlanguage notations of similar communicative units: password [a secret word or phrase that must be used to gain admission to a place] and its synonyms, the watchword, parole, signal. There is a separate notation for the name of the communicative unit that is pronounced in response to the password - countersign [a signal or password given in reply]. In this kind of communicative activity, the information exchanged by the speakers is very specific: it is not at all in the sense of the phrases being pronounced (usually they have arbitrary, fictional meaning), but in their secrecy for the outsiders. Correct / false sharing of the password and response to it is nothing more than a test of "your own, someone else's", not passing such a test (false feedback password) can have very dramatic consequences.

A large number of nominative units in English indicate purely factual communication, that is, easy communication, secular chatter, for the sake of social interaction of 
speakers. The most common in semantics is the lexeme chat [light informal talk; small talk], the synonym of a unit rap [an informal talk, chat] is less frequent. Other synonyms add to this value the estimated (negative) component: chatter [idle, incessant, trivial talk], patter [empty, meaningless talk], prattle [trifling or empty talk; foolish or inconsequential talk; idle or meaningless chatter, babble].

Among these nominations there are numerical lexemes with common values of gossip $=$ spread of rumours, not confirmed by facts, redress. The main among them is the rumour lexeme [widely disseminates with no discernible source; unverified information spread by word of mouth]. The oral channel for obtaining such information is determined by the etymology of this noun, derived from the Latin rumor [noise], and it is not surprising that there are several complete synonyms of the word rumour, which come from the words "sound" semantics: buzz, sound, whisper, hearsay. The hyponimic synonym of rumour is gossip, in the semantics of which is added a refining characteristic of the privacy of distributed information: gossip [rumour of an intimate, personal nature]. The gossip lexeme is the main thing in a long chain of synonyms, each of which defines itself through posting just before [gossip]: dish, comment, report, story, talk, tattle. Several synonymous units emphasize the inappropriateness of spreading rumours: dirt [scandalous or malicious gossip], scandal [malicious gossip], tale [a libelous gossip].

We see that secular conversation, gossiping is a fairly common phenomenon of human communication, as evi- denced in particular by the extensive network of lexical nominations for factual communication, of which 18 are enumerated in lexicographic selection.

Conclusion. Summarizing the analysis of the thematic group communication for the exchange of information, we pay attention to the pronounced estimated component of the grouped units, among which the pseudo-coloured units are much more dominant over the reclamation painted. Among the socially disapproving qualities of human communication, the dominant feature is 1) meaninglessness or petty content, foolishness (definitions of trifle, empty, pointless, fruitless, idle, trivial, foolish, meaningless, intellectually vacuous); 2) stretch, falsehood, verbiage, inconsistency (lengthy, prolonged and tedious, incessant, verbiage, pretentious, inconsequent); 3) insincere, beguiling, misleading, scandalous, malicious, boasting. The socially approving characteristics of communication in accordance with the vocabulary definitions are: 1) serious, effective, convincing, coherent speech, as evidenced by the defining characteristics of effective, orderly, persuasive, serious, careful; 2) constructive communication (to reach agreement, to seek advice). The appropriateness of such communicative behavior is manifested in the presence of positively evaluated sememes in the meaning of the above words, as well as in the use of such definitions as art, skill. The second level of defining analysis explains the presence of the positive colour of the corresponding units: skill; a developed aptitude or ability, art [occupation requiring knowledge or skill].

\section{ЛИТЕРАТУРА}

1. Кодухов В. И. Общее языкознание / В. И. Кодухов: Учебник - Изд. 4-е. - М.: Книжный дом «ЛИБРОКОМ», 2011. $-304 \mathrm{c}$.

2. Кубрякова Е.С. Особенности речевой деятельности и проблемы внутреннего лексикона / Е.С.Кубрякова // Человеческий фактор в языке. Язык и картина мира. - М.: Наука, 1991. - С.141-172.

3. Кубрякова Е. С. Язык и знание: На пути получения знаний о языке: Части речи с когнитивной точки зрения. Роль языка в познании мира / Е. С. Кубрякова / Рос. Академия наук. Ин-т языкознания. - М.: Языки славянской культуры, 2004. - 560 с.

4. Мелентьева Ю.П. О чтении (Размышления о теоретических аспектах чтения). - М.: Издательство «Канон», 2015. $-184 \mathrm{c}$.

5. Никитин М. В. Курс лингвистической семантики / М. В. Никитин: Уч. пособие. - С.-Петербург: Научный центр проблем диалога, 1996.-760 с.

6. Селиверстова О. Н. Труды по семантике / О. Н. Селиверстова. - М.: Языки славянской культуры, 2004. - 960 с

7. Уфимцева А. А. Семантика слова / А. А. Уфимцева // Аспекты семантических исследований - М.: Наука, 1980. - C. 5 - 80.

8. Evans V. Towards a cognitive compositional semantics: An overview of LCCM theory / Vyvyan Evans // Further Insights into Semantics and Lexicography / Ed. by Ulf Magnusson, Henryk Kardela and Adam Glaz. - Lublin: Wydavnictwo UMCS, 20

9. http://dictionary.cambridge.org/dictionary/

10. https://www.merriam-webster.com/

11. http://www.macmillandictionary.com/

12. https://en.oxforddictionaries.com/

\section{REFERENCES}

1. Koduhov V. I. Obshee yazykoznanie / V. I. Koduhov: Uchebnik - Izd. 4-e. - M.: Knizhnyj dom «LIBROKOM», 2011. - 304 s.

2. Kubryakova E.S. Osobennosti rechevoj deyatelnosti i problemy vnutrennego leksikona / E.S.Kubryakova // Chelovecheskij faktor v yazyke. Yazyk i kartina mira. - M.: Nauka, 1991. - S.141-172.

3. Kubryakova E. S. Yazyk i znanie: Na puti polucheniya znanij o yazyke: Chasti rechi s kognitivnoj tochki zreniya. Rol yazyka v poznanii mira / E. S. Kubryakova / Ros. Akademiya nauk. In-t yazykoznaniya. - M.: Yazyki slavyanskoj kultury, 2004. $-560 \mathrm{~s}$.

4. Melenteva Yu.P. O chtenii (Razmyshleniya o teoreticheskih aspektah chteniya). - M.: Izdatelstvo «Kanon», 2015. - $184 \mathrm{~s}$.

5. Nikitin M. V. Kurs lingvisticheskoj semantiki / M. V. Nikitin: Uch. posobie. - S.-Peterburg: Nauchnyj centr problem dialoga, 1996.-760 s.

6. Seliverstova O. N. Trudy po semantike / O. N. Seliverstova. M.: Yazyki slavyanskoj kultury, 2004. $-960 \mathrm{~s}$.

7. Ufimceva A. A. Semantika slova / A. A. Ufimceva // Aspekty semanticheskih issledovanij - M.: Nauka, 1980. - S. 5 80.Evans V. Towards a cognitive compositional semantics: An overview of LCCM theory / Vyvyan Evans // Further Insights into Semantics and Lexicography / Ed. by Ulf Magnusson, Henryk Kardela and Adam Glaz. - Lublin: Wydavnictwo UMCS, 20

8. http://dictionary.cambridge.org/dictionary/

9. https://www.merriam-webster.com/

10. http://www.macmillandictionary.com/

11. https://en.oxforddictionaries.com/ 